\title{
Actors In Academia - Roles Professors Play
}

\author{
Mary Kennedy Minter, Ed.D., Educational Consultant, USA
}

\begin{abstract}
This paper proposes that professors play several actors' roles in the college classroom. Suggestions are made about how to improve and perfect those important roles and responsibilities.
\end{abstract}

Keywords: Professorial roles and responsibilities in the classroom

\section{SETTING THE STAGE}

n order to set the stage for the "actors in academia," the author suggests that the following roles and
responsibilities are the most significant ones for the college/university professor, including some for
students:

1. Actor

2. Communicator

3. Facilitator

4. Trainer/Coach

5. Craftsman (craft of teaching) - this includes the "art of style"

6. Manager (of the classroom)

After 40 years of experience, the author has determined these concepts should be considered very seriously by all who profess to be, not only competent, but highly effective in the classroom. The basic roles are listed below with brief descriptors. Inherent factors related to these roles/responsibilities will also be explored.

\section{PROFESSOR AS AN ACTOR}

Authenticity in the role of actor necessitates knowing your "lines," i.e., knowing your subject matter and "back-story." Back-story is the process of researching the facts about the play, i.e., having full knowledge of the subject that you are teaching and, perhaps most importantly, knowing how to put that subject information into a significant historical, current, and relevant perspective. For example, why should students be interested in the subject? Why is it important for them to understand the "lines" that you deliver on your professorial stage?

In addition, there is an inherent factor in the actor role that the professor must learn to "manage." That factor is the actor's "EGO." The term, itself, sounds like a monster movie character and it can become one if it is not managed/controlled. As the teacher must analyze the other roles to be played in the classroom, the very personal concept of Ego needs to be understood and utilized effectively to allow the teacher to be effective.

Ego" has been defined as: "the self: "A human being, thus, is at all times an organism, an ego, and a member of a society.' (Erik Erikson). Psychoanalysis. The personality component that is conscious, most immediately controls behavior, and is most in touch with external reality." [The American Heritage Dictionary of the English Language.]

An extension or connotation surrounding the "ego" concept is that of "egoism." If a professor becomes preoccupied with her/his own pontificating in a lecture mode and the advancement through the academic ranks via research and writing, then the classroom student learning via effective instruction may suffer. Perhaps we need to re-assess the higher education environment that may breed these negative effects of "ego." 


\section{Suggestions for keeping your professorial "ego" well managed:}

Expect students to meet high standards of learning, but be willing and able to provide the best instruction possible to aid students in achieving those high standards.

College professors (or teachers at any level of education) should work at gaining student respect (over a period of time) by concentrating on developing an authentic self that can be shared with students. The "authentic self" can be defined, denotatively, as "worthy of trust, reliance, or genuine;" connotatively, this "honest" approach may be perceived by students as a strange way for a professor to "act" because it is not the usual authoritative, sometimes false, acting by an instructor.

As you concentrate on being yourself in the classroom, pay particular attention to organizing your teaching (managing the classroom learning activities) so that you provide the best environment for student learning.

\section{Note to the students:}

The author proposes that there is an inherent axiom related to teaching, at any level of education, but especially in higher education: students have to assume the responsibility for the actual learning, i.e., transplanting information into their own cognitive (thinking) processes and then, managing the storage and utilization of that data. Only when students engage in this active learning process of assimilation will real knowledge emerge that can be used and tested in the world outside the classroom. The author does not condone the often used phrase: "If a student has not learned, the teacher has not taught." In contrast, learning should be viewed as a multi-communication highway where (1) teachers must provide well-paved roads to navigate a complex interstate system of learning and provide well-marked signs to help lead the student on the right path (that is, a teacher's responsibility is to provide the best learning environment possible within the classroom "stage"); (2) students must provide the vehicle and it should be well-tuned and efficient for the long trip through a mirage of landscapes. A key point in this brief analogy is that learning in the classroom should be a "two-way street" (two-way communication) where teachers and students learn from each other and from the environments surrounding them.

Professor as a Communicator: Professional actors cannot be truly successful unless they have learned the basic skills of public speaking. [In this descriptive paper, the author is limiting the communication definition to classroom face-to-face interaction with the students because if teaching is done by "on-line computer method" or "videotape/movie venue," then the communication skills are much more expanded and complicated.]

1. Classroom communication includes knowing, practicing, and perfecting the basic public speaking skills.

2. Those public speaking skills include, but are not limited to, the basics of "persuasive and stimulating techniques and methods, empathy, and humor." By "humor," the author is not referring to "telling jokes;" it is risky business trying to be a "stand-up comedian" in the classroom. Rather, humor is described here as demonstrating "humility," i.e., being able to laugh at one's self and above all, being able to admit when you, as the professor/actor, are wrong (or don't know the answer) in the role that is being played and communicated.

3. Perhaps some academicians may prefer the term of "Transformational Communication" (TC) rather than "public speaking" as the concept of a professor's mode of discussion with students. The author's approach is that transformational communication should be inherent in the public speaking skills needed for the classroom. For example, one definition of TC is: "a process that allows people to relate to themselves and others in a self-affirming manner, and a communication model that provides the tools to create empowering relationships. It focuses on .... the way we listen, how we express ourselves, and the attitudes with which we communicate with ourselves and others." 1

4. Visual Aids: In this day of technological advancements, it is very tempting for a professor to rely on such teaching aids as: the infamous Power Point, videos, computer transmitted syllabi, assignments, and other technical-based communication. However, the overuse of these technologies REDUCES the amount of face-to-face communication that can be the life-blood of learning, i.e., the need for interpersonal communication where the professor and the student really get to know each other and can have active 
interplay of ideas. Without this personal touch in education, the teacher and the student become actors on the classroom stage with only their monologues for communications.

\section{FACILITATOR}

An extension of the communicator's role is that of a facilitator. This role is needed by all actors on the academic stage. If you are only "lecturing" on stage, then communication is just a "monologue" and even the best professional actors can only sustain that mode for about 15 minutes. When you use the monologue (lecture), you are playing to a passive audience. However, studies have shown that students want to be active, to interact with that "talking head professor." So what is involved in the role of a facilitator who brings the students into interaction with the "lead actor" (professor) and allows those students to become part of an action-packed play? Perhaps, a professor should study the skills of improvisation acting and go to a "Second City" improvisation show for ideas.

The role of facilitator implies that the professor is "facilitating" action versus lecturing to a passive student audience. So what represents that action? See the "roles of trainer and craftsman" described below.

\section{TRAINER/COACH}

As a philosophical preface to this professor role, some academicians have expressed a disdain for the term "trainer" as not being relative to the higher education environment. Such a viewpoint seems to indicate that "training" should be relegated to lower-level education or to the world of business/industry. However, the author takes a different view of the professor as a "trainer."

Most of our "teaching methods" have their roots in "training methods and techniques" that were standardized and documented during World War II by the armed service (often referred to as "JIT," Job Instructional Training). This teaching process was desperately needed in order to "train" new military and industry workers to learn new skills quickly, but at a very high quality level-it was literally a matter of life or death for those who needed such skills and products. Are our efforts for teaching/training in higher education any less important? We are, after all, educating/training people for the future of our country. These basic training steps should sound familiar to the professor in today's college classroom.

Step 1 - Prepare the trainee. This step includes:

1. Put the person at ease

2. Find out what the person may already know about the job (student audience analysis or pre-testing).

3. Get the person interested in learning the subject.

4. Place the person in the correct position for doing the job (providing a classroom environment conducive to learning).

Step 2-Present the Operation/information (Demonstration). TELL, SHOW, ILLUSTRATE carefully and patiently. This step includes:

1. Stress key points

2. Instruct clearly and completely, taking one point at a time, but no more than the trainee (student) can master.

3. Provide samples of what the completed product will be.

Step 3- Try-out Performance (Practice). This step includes:

1. Test the person by having him perform the job/task.

2. Have the person tell and show you and explain the key points.

3. Ask questions; correct errors. 
Step 4- Follow-up. This step includes:

1. Put the trainee on his own (during standard classroom testing or performance).

2. Check frequently

3. Encourage questions

4. Get the trainee to look for key points

5. Taper off extra coaching and eliminate close follow-up

Does the above listing really look that much different from our higher education process of teaching?

\section{CRAFT OF TEACHING}

This role represents the foundation of all of the above professorial characteristics. Unless professors continue to develop and hone the skills of their "craft," i.e., the skills of teaching through the various roles they play in the classroom, then the author suggests that those professors are not doing justice to themselves or to their students. Both professors and students need to engage in "life-long learning" through continual study of their selected craft and through continual updating and perfecting the skills needed for that craft. ${ }^{2}$

A very important part of a professor's "craft" is to provide a role model, i.e., to be able to demonstrate that which you are asking students to learn. This does not mean that you always have to provide a "perfect" sample. For example, the author has spent many years teaching "craft-type" venues, such as: public speaking, interpersonal communication, organizational communication, and basic management skills. As the professor, the author always gives a SAMPLE speech, activity, or product like the one that students are expected to present. After the author's sample, students are required to complete a detailed evaluation of the professor's sample presentation/product. The results are: the professor learns from the student feedback (how to improve her/his sample) and the students learn what errors could be made in such a communication and therefore, how to better prepare for their own presentation. ${ }^{3}$

Another crucial part of the "craft of teaching" is how you present and facilitate the methods of teaching/training. In a modern, flexible classroom environment, the author proposes a multi-method approach. For example, it has already been mentioned that the "lecture only" approach results in students being placed in a passive state for learning. Enhancing the lecture with audio-visual aids (e.g, power point, films, charts, recordings, music, etc.) can help alter the one-way (lecture) communication and aid student learning. However, such a one-way communication still does not get the students actively involved in the learning process. Even a "question and answer" period at the end of a visually enhanced lecture is limiting. The author proposes a multi-method approach which goes beyond the traditional lecture method. For example:

1. Samples of assignments can be very helpful; however, such examples may lead students to "copying the sample" and not stimulate their own creativity and originality.

2. Demonstrations are very helpful when this method of instructing includes a time for students to practice the assignment and receive feedback on that practice.

3. Field trips, when feasible, are an excellent method of putting learning into perspective with the "real world" environment.

4. Case studies can definitely enhance the reality understanding of a problem. If managed properly as a classroom teaching method, case studies can get the students interested in the concepts being taught and provide a critical thinking exercise in the process.

5. Role-play and other simulations are interactive methods for providing students with "practice" for a final, graded assignment.

6. The use of video taping the student who is completing an oral presentation is perhaps the best method for giving the learner immediate feedback that she/he can use to self-critique. The author has found that after oral and written critique of the students work, the video tape will act as specific feedback for the student to actually SEE what needs to be corrected. After using this method of feedback to the student, the author has determined that it is one of the best learning tools, i.e., students will learn how to "critique themselves" and that can be one of their best skills to take with them into the real world of work. 
7. Actual, "on-the-job" experience for students: If possible, a professor should help the student arrange for an "on-the-job" experience, after which they report on their feedback in implementing the classroom learning concepts/skills. Examples of outside-the-class experience that the author has used in the past are:

a. Students present a speech for a "live audience" in the environment in which they work for a living or a related situation.

b. Students complete an actual job interview after role-playing that interview situation in the classroom.

Notice that in outlining the teaching/training/coaching methods listed above that the methods evolve from the minimum level of student involvement - the lecture to the maximum level of involvement with direct, purposeful experience within a real-life situation/environment. ${ }^{4}$

Professors in the Role of Manager: Although professors may not perceive this factor, all the roles described above include characteristics of a business manager. For example, in an interview study of 402 highly effective business managers, the following behavioral characteristics were identified as the top 10; each of these characteristics can be related to a professor's role as a manager:

1. Verbal communication (including listening) (related to a professor's role as a public speaker and on-going dialogue with students)

2. Managing time and stress (related to the multi-tasks expected of professors in higher education, e.g., teaching, research, publications, and committee work)

3. Managing individual decisions (related to a professor's subject matter emphasis and syllabi decisions, as well as, the dynamics of communication within the day-to-day classroom discussions)

4. Recognizing, defining, and solving problems (related to a professor's managing of subject matter or classroom's interpersonal communication)

5. Motivating and influencing others (related to a professor's skill, technique, and style)

6. Delegating (related to professors involving students in the learning process)

7. Setting goals and articulating a vision (related to professors ability for clarifying student learning objectives and teaching objectives)

8. Self-awareness (a professor's discovery and willingness to demonstrate her/his authentic self)

9. Team building (a professor's skill, technique, and style of engaging the students in the synergy of learning)

10. Managing conflict (a professor's skill of confronting conflict and managing an appropriate solution to the problem as analyzed). ${ }^{5}$

\section{CONCLUSION: STYLE FOR THE ACTOR IN ACADEMIA}

The subject of roles played by professors would not be complete without a reference to the styles of teaching and the learning styles of students.

The author proposes that the best style of teaching involves sensitivity to the concept of synergy in the classroom. For our purposes here, synergy can be defined as cooperative action between the teacher and the students that produces a "total effect that is greater than the sum of the effects taken independently. This definition is interpreted to indicate a different teaching style. Such a style requires a confident teacher who is willing to accept the following risks: (1) the teacher is not always the expert, (2) the teacher is not always needed, (3) the teacher is not always in the spotlight."

As for the learning styles of students, synapse (synaptic) is the key term. "Synapse is the point at which a nervous impulse passes from one neuron to another. This definition is interpreted to indicate a different learning style. The style requires a self-referenced student. Self-referenced is a term used for self-motivation, diversified needs and an established 'image path.,",

The key concepts of teaching style are illustrated by B.K. Zanger in her model called "image path." An image path is composed of "skill, technique, and style." 
1. The teacher must demonstrate skill in teaching which includes knowing the basic foundations of the subject matter and being able to deliver effective teaching methods that necessitate skill competency in speaking, writing and math calculations (for fair grading practices).

2. Technique refers to the "development of basic skills into specific approaches within defined ranges of abilities." For the teacher/professor this means honing/developing those basic skills in the areas of public speaking, facilitating a multi-method teaching approach in the classroom and demonstrating an authentic, respectful self to your students.

3. Note: Rubrics used for evaluating professors' performance should include measurement of both basic skills and techniques used to implement those skills.

4. Style is defined by B.K. Zanger as the coup de grace: "After you have skill and technique, you add your signature to the performance. .." Each professor develops her/his own "style" of teaching. For example, style is composed of: the professor's individual personality, years of experience in teaching, depth of subject knowledge and teaching methods, effects of the teaching environment, and performance of skills/techniques. In essence, the paradigm suggested is one of an open-system concept that implies continuous skill practice, changes in technique, and perfection of style. Therefore, the actors in academia must be engaged in "life-long learning," both with their students and in their own profession.

\section{AUTHOR INFORMATION}

Mary Kennedy Minter, Ed. D., University has been a college teacher for over 30 years and specializes in faculty development consulting. She has taught instructional communication and business management at Texas Christian University, U. of Texas, Arlington, Texas Wesleyan University, University of Akron, and Cleveland State University.

Her degrees are: doctorate in Higher Education Administration, U. of Michigan; Master's degree in Organizational Communication/Industrial Relations from Purdue University; and Bachelor of Arts from Ohio.

\section{Footnotes}

${ }^{1} 2005$ Institute for Transformational Communications. http://www.itranscomm.com

${ }^{2}$ McKeachie, Wilbert J. (1999)._McKeachie's Teaching Tips: Strategies, Research, and Theory for College and University Teachers. Boston: Houghton Mifflin. p. 74.

${ }^{3}$ Ibid. pp. 75-83.

${ }^{4}$ Angelo, T.A. \& Cross, K.P. (1993). Classroom Assessment Techniques (2 ${ }^{\text {nd }}$ Ed.). San Francisco, CA: Jossey-Bass Publishers.

${ }^{5}$ Whetten, David A. \& Cameron, Kim S. (1998). Developing Management Skills. Reading, Mass.: Addison-Wesley. p.7.

${ }^{6}$ Zanger, Beverly R. K. (1991). "The Synergistic Teacher and the Synaptic Student”, Unpublished paper: Bowling Green State University. p. 2

${ }^{7}$ Ibid.p. 2.

${ }^{8}$ Parks, Janet B. \& Zanger, Beverly R. K. (1990). Sport \& Fitness Management (Career Strategies and Professional Content). Champaign, IL: Human Kinetics Books. p.156.

\section{REFERENCES}

1. Cooper, Pamela J. \& Simonds, Cheri J. (2003). Communication for the Classroom Teacher ( $7^{\text {th }}$ Ed.). Boston, Mass.: Allyn and Bacon Publishers.

2. Organization Design and Development, Inc. (2003). What's My Communication Style? King of Prussia, PA: HRDQ. 